LII.-On the Lucernaria cyathiformis of Sars. By P. H. Gosse, Esq., F.R.S., A.L.S.

To the Editors of the Annals and Magazine of Natural History.

\title{
Genthemen,
}

In the 'Quarterly Journal of Microscopical Science' for this month, Professor Allman has described and figured what he considers to be the Lucernaria cyathiformis of Sars, instituting for it a new genus, under the name of Carduella. I feel sure he was not aware that I had already separated it from Lucernaria, under the generic name of Depastrum, in the 'Annals' for June 1858, page $419 *$.

But I also had found what I supposed to be the L.cyathiformis on repeated occasions at Weymouth, viz. in the spring and summer of 1853. The specimens were in each case affixed to the under surfaces of stones at very low water. I had made careful magnified figures of my specimens, which I forward with this letter. It is manifest that Prof. Allman's and mine do not represent the same species; and, on comparing each with Sars's diagnosis (as cited by Johnston, Br. Zooph. i. 474, the only reference at my command), it appears that the Orkney species agrees with the Norwegian, while the Weymouth species differs from it.

The most important points of difference are: 1. the disk in Depastrum cyathiforme is circular and entire, in D. stellifrons (by which name I propose to distinguish the southern type) distinctly 8 -angled; 2 . the tentacles in D. cyathiforme are unifarious and equal, in D. stellifrons bi- or tri-farious and notably unequal; 3 . the tentacles in $D$. cyathiforme spring from a circle within the margin, in $D$. stellifrons from the margin or without it; 4 . in D. cyathiforme the tentacles are represented as very regularly capitate; in $D$. stellifrons the distinction between the pedicle and the head is much less marked, and they are frequently rather clavate than capitate; 5 . the hue in $D$. cyathiforme is represented as brownish-red; in D. stellifrons it was (in my specimens) a dull olive, becoming pale on the disk, and tinged with umber on the body, the tentacles and ovaries white. The disk in D. stellifrons was studded with minute white granules, arranged in eight radiating groups.

It follows that a new generic diagnosis is needed for this form; for both the one I had given for Depastrum and the one Prof.

* In the 3rd vol. of the 'Histoire Naturelle des Coralliaires,' just published (1860), M. Milne-Edwards has given a third generic title to the same animal, viz. that of Calicinaria. 
Mr. P. H. Gosse on the Lucernaria cyathiformis of Sars. 481

Allman has now given for Carduella are defective, each containing characters that belong to the particular species respectively. The diagnoses of both genus and species may be corrected thus :-

\section{Depastrum, Gosse.}

Corpus repente contractum, et supra et infra alvum.

\section{D. cyathiforme, Sars.}

Discus circularis; tentacula monosticha, æqualia, intra marginem disci salientia.
D. stellifrons, Gosse.

Discus octangularis ; tentacula di- tristicha, inæqualia, ad marginem disci salientia, inter angulos.

I am, Gentlemen,
Your obedient Servant,

Torquay, April 7, 1860.

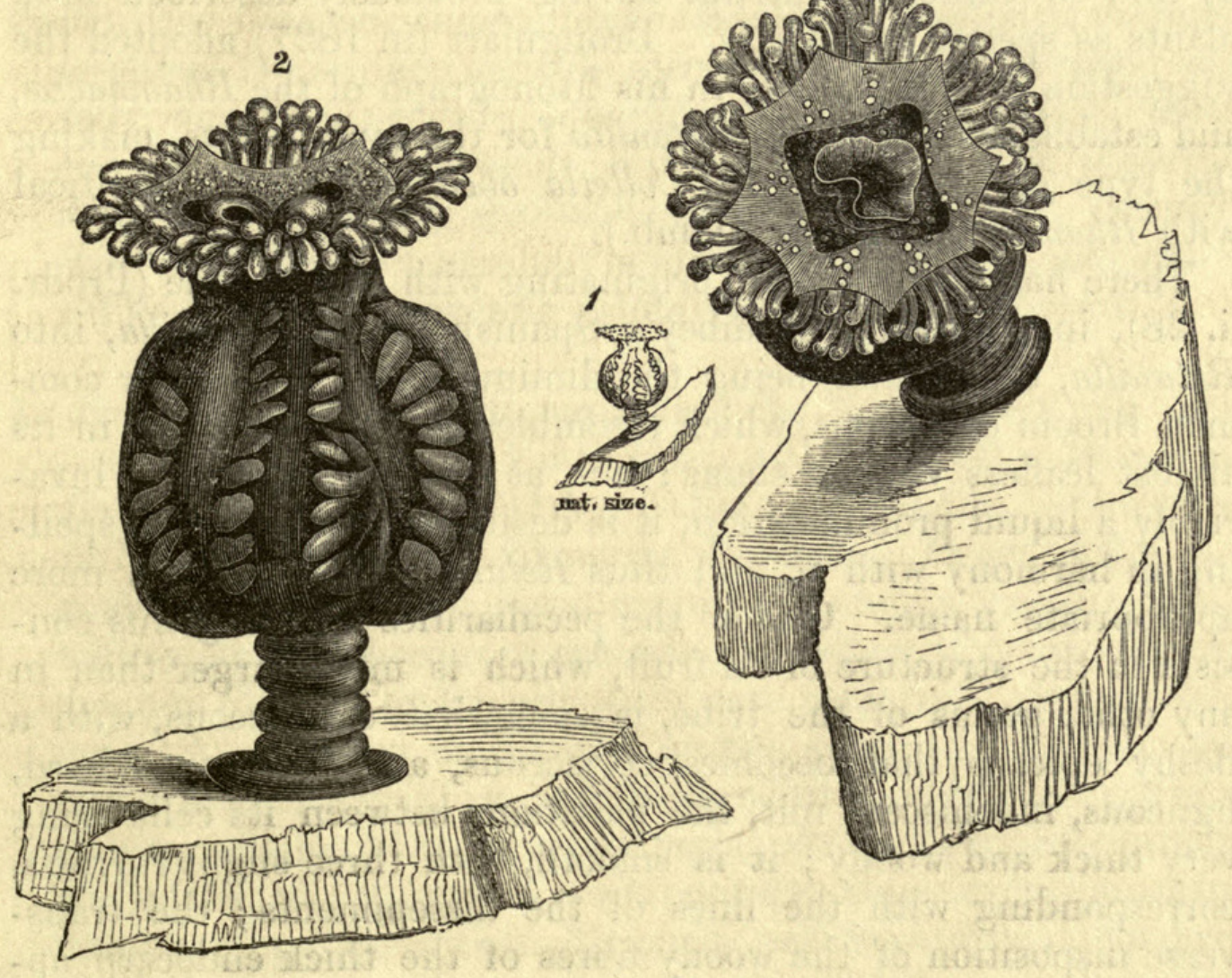

Fig. 1, Depastrum stellifrons, natural size.

Fig. 2. The same, magnified, lateral aspect.

Fig. 3. The same, magnified, vertical aspect. 


\section{$2 \mathrm{BHL}$ Biodiversity Heritage Library}

Gosse, Philip Henry. 1860. "LII.-On the Lucernaria cyathiformis of Sars." The Annals and magazine of natural history; zoology, botany, and geology 5, 480-481.

View This Item Online: https://www.biodiversitylibrary.org/item/19558

Permalink: https://www.biodiversitylibrary.org/partpdf/39870

\section{Holding Institution}

Natural History Museum Library, London

\section{Sponsored by}

Natural History Museum Library, London

\section{Copyright \& Reuse}

Copyright Status: Public domain. The BHL considers that this work is no longer under copyright protection.

This document was created from content at the Biodiversity Heritage Library, the world's largest open access digital library for biodiversity literature and archives. Visit BHL at https://www.biodiversitylibrary.org. 